\title{
Biochar amendment regulated growth, physiological, and biochemical responses of conifer in red soil
}

\author{
Muhammad Waqqas Khan Tarin (1), \\ Lili Fan ${ }^{(2)}$, \\ Yueqin $\mathrm{Cai}^{(1)}$, \\ Muhammad Tayyab ${ }^{(3)}$, \\ Lingyan Chen ${ }^{(1)}$, \\ Tianyou $\mathrm{He}^{(1)}$, \\ Jundong Rong ${ }^{(2)}$, \\ Yushan Zheng ${ }^{(1-2)}$
}

The addition of Biochar (BC) into the soil is expected to improve soil physicochemical properties and plant growth. However, few studies have verified such an effect on the growth and physiological characteristics of conifers. The current study aims to assess the efficacy of novel physiological parameters as an indicator for assessing the impact of hardwood biochar (BH) on the development of Fokienia hodginsii seedlings to strengthen our understanding of the impacts of the $\mathrm{BH}$ on soil to optimize the achievement of $\mathrm{BC}$-based restoration projects. The $\mathrm{BH}$ was applied to the soil under four different levels $(0,5,20$, and $80 \mathrm{~g} \mathrm{Kg}^{-1}$ of soil) to assess their influence on the leave's photosynthetic pigments, photosynthesis $(\mathrm{Pn})$, and biochemical traits of $F$. hodginsii seedlings in four different seasons, and on biomass and soil physicochemical properties at final harvest under greenhouse conditions for one year. In the first two seasons, $\mathrm{BH} 20$ and $\mathrm{BH} 80$ amended seedlings responded with an improved photosynthetic rate with more production of photosynthetic pigments and biochemical attributes. However, none of the BC doses increased the Pn of seedlings in the final season. Nonetheless, after one year a rise in soil $\mathrm{pH}$ as well as $\mathrm{P}$ and $\mathrm{K}$ availability resulted in a maximum $25 \%$ increase in biomass of $F$. hodginsii under $\mathrm{BH} 80$ amendments. Our findings reveal that the incorporation of $\mathrm{BH}(20$ and $80 \mathrm{~g} \mathrm{~kg}^{-1}$ of soil) has a substantial positive effect on seedling biomass and soil fertility. However, the application of BH into acidic soils may be effective in restoring degraded soils if initially combined with fertilizers. We recommend a careful approach to the selection of BC because its influence may vary between different soil types, plant species, and BC feedstocks.

Keywords: Fokienia hodginsii, Hardwood Biochar, Restoration, Photosynthesis

cently, the use of biochar $(B C)$ as an organic amendment has become an alternative to returning biomass into the soil to address numerous agronomic and environmental problems (Nobile et al. 2019). BC is a rich carbonaceous material obtained from biomass via the thermochemical process (pyrolysis) under limited or no oxygen (Videgain-Marco et al. 2020). Owing to its advantageous properties (rich carbon C and larger surface area), its application into the soil is expected to improve the soil fertility and biological activity (Levesque et al. 2018). Its compositions make it stable in many soils from a hundred years to potentially a thousand years (Haefele et al. 2011).

Fokienia hodginsii (Dunn) A. Henry \& H.H. Thomas (Fujian cypress) is a valuable tree species native to southern China, Vietnam, and Laos. It has received much attention in China because of its high-quality timber (export) and aromatic essential oil (Siamwood essential oil). During the last few decades, its populations have been reduced and recently it is listed as threatened in the red list of IUCN (International Union for Conservation of Nature).

Large areas in tropical and subtropical regions of southern China are characterized by acidic soils, which hinders plant growth by affecting many physiological processes (Haynes \& Mokolobate 2001). The physio- logical characteristics of a plant are regarded as a primary indicator of its health and fitness. For instance, photosynthetic activity mainly relies on the concentration of chlorophyll pigments (Chen et al. 2018), which is related to the nitrogen $(\mathrm{N})$ status of the plant, and carotenoid concentration is a proxy of plant sensitivity to light intensity (Tarin et al. 2020). Biochemical traits such as amino acids, total soluble proteins, etc. are environmentally controlled features that vary in different seasons (Zemanova et al. 2017). Yet, there is limited information regarding the response of the physiological attributes of forest trees to the $B C$ amendment to develop sustainable strategies for forest management.

Several investigations have been focused on the impact of $B C$ as an amendment on plant growth and soil, mostly on crops rather than forest tree species. For instance, Uzoma et al. (2011) reported that $B C$ amended soil increased the soil cation exchange capacity and the availability of nutrients which improved maize growth and yield. Moreover, seedlings of Solanum lycopersicum and Oryza sativa emerged rapidly under soil amended with rice husk BC (Anyanwu et al. 2018). Lusiba et al. (2018) demonstrated that the addition of $B C$ significantly enhanced the biomass of chickpea combined with $\mathrm{P}$ fertilizer in clay 
soil. Recently, BC mixed in growing media promoted the biomass of lettuce and basi (Nobile et al. 2019).

To date, there are limited $B C$ studies that support such an influence on the physiology and biochemical of woody plants in forest soils. For example, Choi et al. (2009) demonstrated that the $\mathrm{BC}$ amendment to soil significantly increased photosynthetic activity in Pinus densiflora. Omil et al. (2013) reported the positive effects of $B C$ and mixed wood ash on growth in Pinus radiata. Tree seedlings growth responded positively under charcoal amended soil with low phosphorus (Pluchon et al. 2014). Zahedifar \& Najafian (2017) noticed the positive effect of $B C$ on height, leaf area, and nutrient uptake $(\mathrm{N}, \mathrm{P}$, and $\mathrm{K}$ ) of Ocimum basilicum $\mathrm{L}$. grown on calcareous soil. Bu et al. (2020) suggested that adding 1-2\% of BC greatly increased the germination of seeds and the seedling development of Robinia pseudoacacia L. Conversely, the BC amendment to soil gave opposing results on Prunella vulgaris photosynthesis (Thomas et al. 2013), while had no effect on the growth of Douglas-fir seedlings (Sarauer \& Coleman 2018), thus demonstrating that plant responses to the incorporation of $B C$ into the soil are highly inconsistent.

Most of the above BC studies focused on the analysis of biomass production. However, to understand how plant growth can be affected by $B C$, further parameters related to plant physiological status need to be explored. In view of this, the current study aims to assess the efficacy of physiological parameters as an indicator of the impact of $B C$ amended soil on $F$. hodginsii seedling development.

The main goals of this study were to investigate the influence of varying levels ( 0 , 5,20 , and $80 \mathrm{~g} \mathrm{Kg}^{-1}$ of soil) of $\mathrm{BH}$ amendment to red soil on: (i) photosynthetic pigments, biochemicals, and gas exchange attributes of $F$. hodginsii seedlings in four different seasons; (ii) biomass and soil physicochemical properties at final harvest under greenhouse conditions for one year. We hypothesized an overall positive effect of $\mathrm{BH}$ addition to soil fertility and key physiological features of $F$. hodginsii seedlings.

\section{Material and methods}

\section{Description of the study area and design}

The present work was carried out at the Bamboo Institute of Fujian Agriculture and Forestry University, Fuzhou, China. Hardwood biochar $(\mathrm{BH})$ was produced from $\mathrm{Pi}$ nus massoniana and Cunninghamia lanceolata at $420^{\circ} \mathrm{C}$, purchased from Nanjing Qinfeng Straw Technology Co. Ltd., China. The physicochemical properties of the soil and BC were both characterized prior to its application (Tab. S1 in Supplementary material). In March 2017, one-year-old seedlings of $F$. hodginsii were subjected to four different treatments characterized by increasing $B C$ addition to soil, namely: (i) Bo (no biochar/control); (ii) $\mathrm{BH}_{5}$ (5 $\mathrm{g} \mathrm{kg}^{-1}$ of soil); (iii) $\mathrm{BH} 20$ (20 $\mathrm{g} \mathrm{kg}^{-1}$ of soil); and $\mathrm{BH} 80$ (80 g $\mathrm{kg}^{-1}$ of soil). Seedlings were collected from forest nursery (Anxi County, Fujian, China). A total of 32 seedlings were grown in PVC pots (height: $18 \mathrm{~cm}$; top circumference: 62 $\mathrm{cm}$; bottom circumference: $52 \mathrm{~cm}$; soil weight: $5 \mathrm{~kg}$ per pot) under four different $B C$ levels in a completely randomized design. In order to produce healthy seedlings, all replicates were placed in a glasshouse with natural light and full irrigation. In addition, after 15 days from the establishment, 10 grams per pot of NPK fertilizer (15:15:15) was applied as recommended by the Anxi Forest Nursery. After three months (June 2017), physiological attributes (gas exchange) were recorded and leaf tissues were analyzed for photosynthetic pigments and biochemical composition. Similarly, these parameters were systematically recorded at three-month intervals on September 2017, December 2017, and March 2018. Besides, soil physicochemical properties, plant morphological attributes (height and diameter), and total biomass were determined at the final harvest.

\section{Characterization of biochar and soil physicochemical properties}

Before the experiment, both soil and $B C$ were assessed for basic physicochemical properties (see Tab. S2 in Supplementary material). In addition, soil samples were taken from each replicate at the final harvest to assess the physicochemical properties of the soil, including $\mathrm{pH}$, total nitrogen $(\mathrm{N})$, total carbon (C), total and available phosphorus ( $\mathrm{P})$, and available potassium $(K)$. The soil samples were air-dried and then passed through a $2 / 0.149 \mathrm{~mm}$ sieve and the fractions were analyzed for selected physicochemical properties. The soil $\mathrm{pH}$ (1:2.5 soil/water suspensions) was recorded using a portable $\mathrm{pH}$ meter (INESA Science Instrument Co., Ltd., Shanghai, China) as described by Tarin et al. (2020). Total $\mathrm{N}$ and soil TC were determined through the Elemental analyzer (Thermo Scientific ${ }^{\mathrm{TM}}$, Waltham, MA, USA). Total and available $P$ were measured using the alkali fusion-Mo-Sb anti-colorimetry method on the spectrophotometer (BioTek, Epoch2, Winooski, VT, USA) as described by Watanabe \& Olsen 1965. The extraction of available potassium (AK) was carried out using a flame photometer (FP640 ${ }^{\circledR}$, AOPU Analytical Instruments, Shanghai, China) in ammonium acetate solution according to Pansu \& Gautheyrou (2007).

\section{Light-response curves and gas exchange}

During each season (June 2017 to March 2018), upper-middle healthy leaves from each replicate were selected for recording gas exchange attributes and constructing light-response curves of $\mathrm{Pn}$. All the measurements were conducted between 09:00 and 11:30 a.m. Before each measurement, photo-induction of $30 \mathrm{mins}$ at $800 \mu \mathrm{mol} \mathrm{m}^{-2}$ $\mathrm{s}^{-1}$ was ensured as suggested by Chen et al.
(2018). The photosynthetic photon flux density (PPFD) at 15 different concentrations $(2000,1600,1200,1000,800,600$, $400,200,100,80,60,40,20,10$ and $0 \mu \mathrm{mol}$ $\mathrm{m}^{-2} \mathrm{~s}^{-1}$ ) and single $\mathrm{CO}_{2}$ concentration (400 $\left.\mu \mathrm{mol} \mathrm{mol}{ }^{-1}\right)$ were fixed in a portable Pn system (LI-6400XT ${ }^{\oplus}$, LI-COR Biosciences, Lincoln, NE, USA). We used a modified model of rectangular hyperbola with highly fitted data (approx. $R^{2}>0.99$ ) for the light-response curves and photosynthetic parameters as described by Chen et al. (2018). The detailed information and equations of the modified model of rectangular hyperbola are presented in Appendix 2 (Supplementary material).

\section{Photosynthetic pigment contents and leaf biochemical traits}

In each season, healthy leaves from seedlings were collected, washed, and dried on filter paper to assess the concentrations of biochemicals. The photosynthetic pigments were determined immediately after the collection of the samples by retaining leaves in $80 \%$ acetone for $48-72 \mathrm{~h}$ in darkness at $4{ }^{\circ} \mathrm{C}$ until their color changed completely to white. Further absorbance of extractions for chlorophylls (a, b), total, and carotenoids were determined at 663, 645, and $470 \mathrm{~nm}$, respectively, and calculated by using the equations of Lichtenthaler (1987) (Appendix 1 in Supplementary material).

The total soluble protein (TSP) at absorbance $595 \mathrm{~nm}$ and amino acids at $650 \mathrm{~nm}$ was determined following the procedures of Bradford (1976). The concentration of ascorbic acid (absorbance at $536 \mathrm{~nm}$ ) was determined as described by Keller \& Schwager (1977). Soluble sugars (absorbance at $620 \mathrm{~nm}$ ) were estimated with the Anthrone reagent (Cakmak \& Horst 1991). The equations and formulas used for calculations are described in Appendix 1 (Supplementary material).

\section{Determination of morphology and \\ biomass}

Before the final harvest, the height and diameter of seedlings were determined using a diameter tape and a vernier caliper, respectively. To determine biomass, all the seedlings were uprooted, washed with care, dried on filter paper, and fresh weight was examined. These seedlings were then tagged and oven-dried at $80^{\circ} \mathrm{C}$ for $48 \mathrm{~h}$ to record dry weight.

\section{Statistical analysis}

All the data are expressed as means and standard errors. Analysis of variance (ANOVA) was performed using SPSS ${ }^{\circledR}$ ver. 17.0 (SPSS Inc., Chicago, IL, USA) to determine the effect of soil BH treatments, and Tukey-HSD test was used to identify significant differences between mean treatments. The softwares Origin ${ }^{\circledR}$ v. 8.5 (OriginLab Corp., Northampton, MS, USA) and Prism v. 8.0.1 (GraphPad, San Diego, CA, USA) were used to fit the light response curves and produce graphs, respectively. 

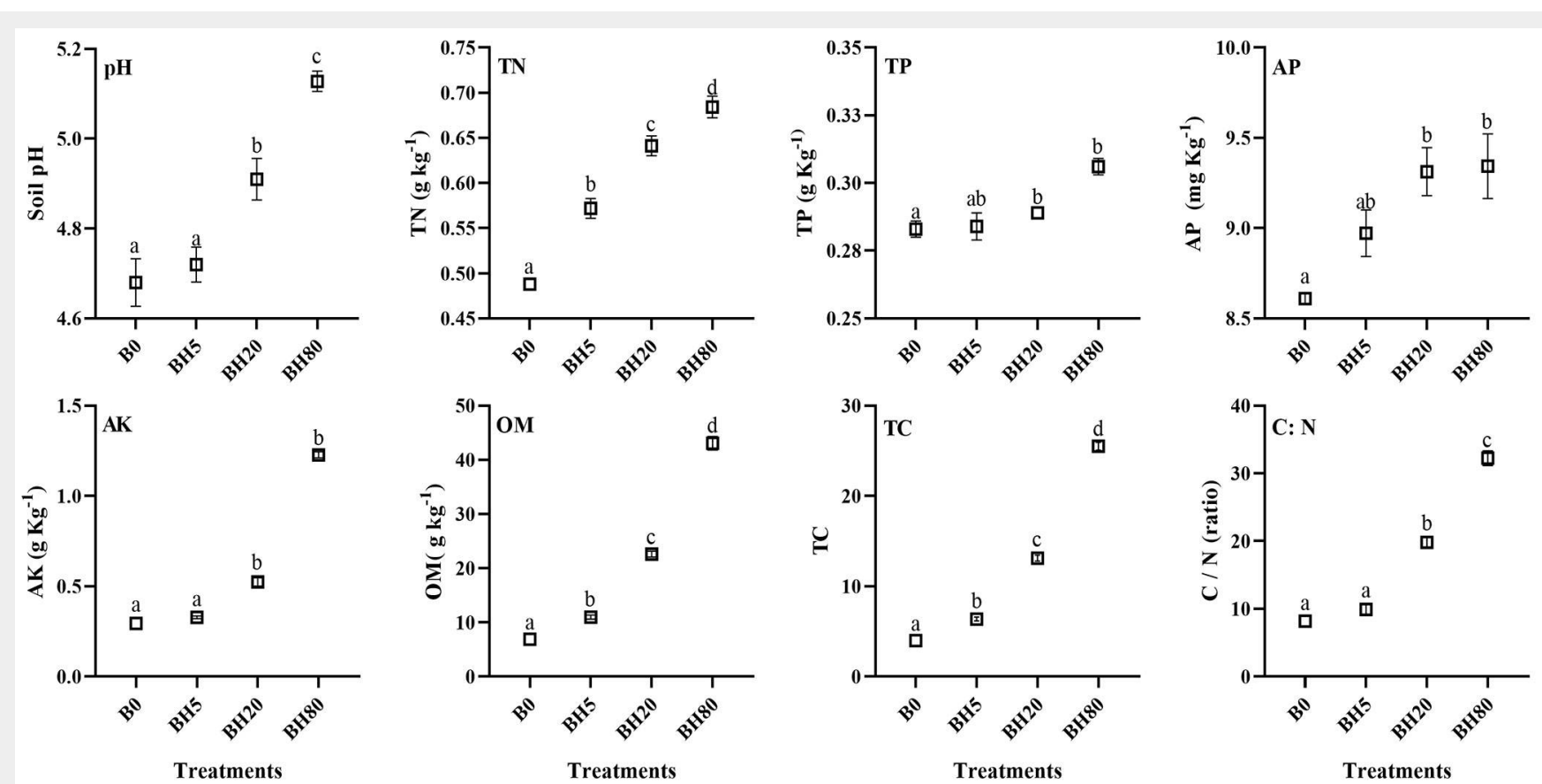

Fig. 1 - Physicochemical properties of soil treated with different levels of hardwood biochar (BH). (Bo): control soil without hardwood biochar amendment; (BH5): hardwood biochar-amended soil at $5 \mathrm{~g} \mathrm{~kg}^{-1}$; (BH2O): hardwood biochar-amended soil at $20 \mathrm{~g} \mathrm{~kg}^{-1}$; (BH80): hardwood biochar-amended soil at $80 \mathrm{~g} \mathrm{~kg}^{-1}$, respectively. (TN): total nitrogen; (TP): total phosphorous; (AP): available phosphorous; (AK): available potassium; (OM): organic matter; (TC): total carbon. Significant differences $(p<0.05)$ among various treatments are shown by various letters. Vertical bars represent the standard error of the mean $(n=4)$.

\section{Results}

Influence of $\mathrm{BC}$ on physicochemical properties of soil

The increase in $B C$ application rates resulted in a significant $(p<0.05)$ rise in soil $\mathrm{pH}$ under $\mathrm{BH} 2 \mathrm{O}$ and $\mathrm{BH} 8 \mathrm{O}$ treatments compared with $\mathrm{Bo}$ and $\mathrm{BH}_{5}$. Total nitrogen (TN), total carbon (TC), and organic matter $(\mathrm{OM})$ content increased significantly $(\mathrm{p}<$ 0.05 ) in all BH amended soils over Bo (Fig. 1). Moreover, among each $\mathrm{BH}$ levels, there was no significant difference $(p<0.05)$ for total phosphorus (TP) and available phosphorus (AP) contents. However, compared to Bo, TP, AP, and AK contents increased significantly $(p<0.05)$ under $\mathrm{BH}_{2} \mathrm{O}$ and BH80 amendments.

\section{Influence of $B C$ on photosynthetic} pigments and photosynthesis

Overall, seedlings treated with $\mathrm{BH} 80$ showed a significant impact on total chlorophyll (TC) concentrations throughout the year as compared to Bo (Fig. 2). At first season (June 2017), all BH amended seedling's TC concentrations were significantly $(p<$ 0.05 ) higher than $\mathrm{BO}$, and $\mathrm{BH} 80$ treated seedlings effectively increased their TC concentrations, with an increase of $34 \%$ compared to Bo (Fig. 2a). During the second season (September 2017), except for $\mathrm{BH} 8 \mathrm{O}$, none of the other BC levels significantly affected TC concentrations (Fig. 2b), and an increase of $9 \%$ was observed in TC concentrations for $\mathrm{BH} 8 \mathrm{O}$ treated seedlings
Fig. 2 - Photosynthetic pigments concentrations in four seasons under various level of hardwood biochar. TC and

CARO indicate total chlorophyll and carotenoid, respectively. (Bo): control soil without hardwood biochar amendment; ( $\mathrm{BH} 5)$ : hardwood biocharamended soil at $5 \mathrm{~g} \mathrm{~kg}^{-1}$; ( $\left.\mathrm{BH} 2 \mathrm{O}\right)$ : hardwood biochar-amended soil at $20 \mathrm{~g} \mathrm{~kg}^{-1}$;

(BH80): hardwood biochar-amended soil at $80 \mathrm{~g} \mathrm{~kg}^{-1}$, respectively. (a): $1^{\text {st }}$ season (June 2017); (b): $2^{\text {nd }}$ season (September 2017); (c): $3^{\text {rd }}$ season (December 2017); (d): $4^{\text {th }}$ season (March 2018). Different letters indicate significant differences ( $p<0.05)$ among treatments. Vertical bars represent the standard error of the mean $(n=4)$.
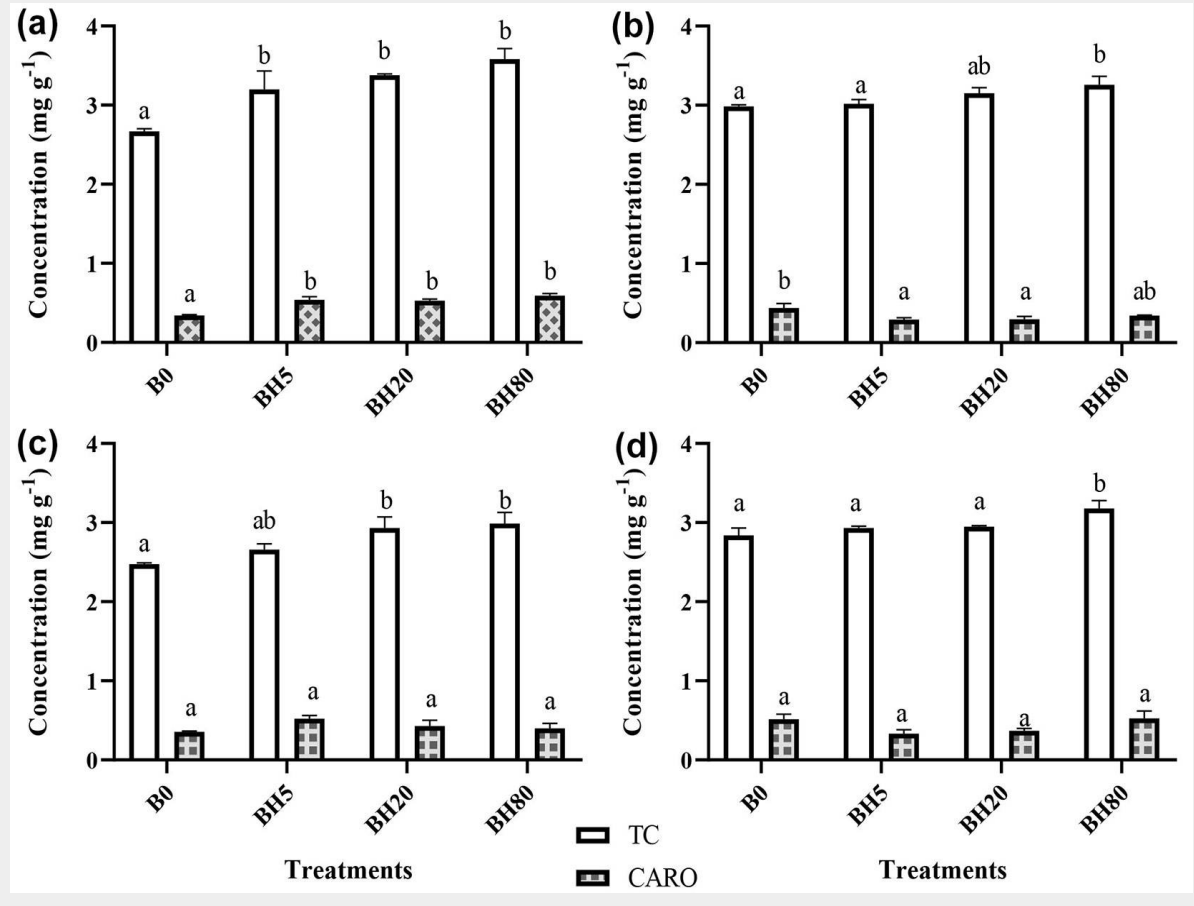
Tab. 1 - Season-wise comparison in photosynthetic parameters of seedlings treated with varying levels of hardwood biochar (BH). (a): initial slope; (Pn-max): maximum photosynthetic rate; (LSP): light saturation point; (LCP): light compensation point; (Rd): rate of dark respiration; $\left(\mathrm{R}^{2}\right)$ : adjusted $\mathrm{R}^{2}$; $(\mathrm{BO})$ : control soil without hardwood biochar amendment; ( $\left.\mathrm{BH} 5\right)$ : hardwood biochar-amended soil at $5 \mathrm{~g} \mathrm{~kg}^{-1}$; (BH20): hardwood biochar-amended soil at $20 \mathrm{~g} \mathrm{~kg}^{-1}$; (BH80): hardwood biochar-amended soil at $80 \mathrm{~g} \mathrm{~kg}^{-1}$. Significant differences $(p<0.05)$ among treatments are indicated by different letters. Values are means \pm standard errors $(n=3)$.

\begin{tabular}{|c|c|c|c|c|c|c|c|}
\hline Date & Treatments & $\alpha$ & 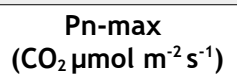 & 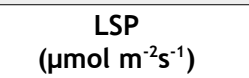 & 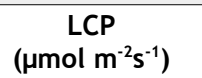 & 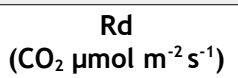 & $\mathbf{R}^{2}$ \\
\hline \multirow[t]{4}{*}{ Jun-17 } & BO & $0.06 \pm 0.01^{a}$ & $3.48 \pm 0.38^{a}$ & $745.17 \pm 79.82^{a}$ & $16.01 \pm 4.88^{b}$ & $0.81 \pm 0.07^{a}$ & $0.98 \pm 0.07^{\mathrm{a}}$ \\
\hline & BH5 & $0.10 \pm 0.01 \mathrm{ab}$ & $5.42 \pm 0.34^{b}$ & $948.51 \pm 6.86^{a b}$ & $8.57 \pm 2.55^{b}$ & $0.89 \pm 0.28^{a}$ & $0.98 \pm 0.01^{\mathrm{a}}$ \\
\hline & $\mathrm{BH} 20$ & $0.09 \pm 0.01 \mathrm{ab}$ & $6.32 \pm 0.08 \mathrm{bc}$ & $856.35 \pm 22.38$ ab & $3.61 \pm 1.36^{\mathrm{a}}$ & $0.35 \pm 0.13^{\mathrm{a}}$ & $0.99 \pm 0.01^{\mathrm{a}}$ \\
\hline & $\mathrm{BH} 80$ & $0.10 \pm 0.01^{b}$ & $6.72 \pm 0.34^{c}$ & $1111.30 \pm 131.27^{b}$ & $5.025 \pm 0.95^{a}$ & $0.53 \pm 0.12^{a}$ & $0.99 \pm 0.01^{\mathrm{a}}$ \\
\hline \multirow[t]{4}{*}{ Sep-17 } & BO & $0.08 \pm 0.03^{a}$ & $5.12 \pm 0.15^{a}$ & $729.30 \pm 31.42^{a}$ & $5.46 \pm 1.77^{a}$ & $0.47 \pm 0.16^{\mathrm{a}}$ & $0.98 \pm 0.02^{a}$ \\
\hline & BH5 & $0.08 \pm 0.04^{a}$ & $5.53 \pm 0.49^{a}$ & $853.07 \pm 88.36$ ab & $4.873 \pm 1.91^{a}$ & $0.42 \pm 0.17^{a}$ & $0.99 \pm 0.04^{\mathrm{a}}$ \\
\hline & $\mathrm{BH} 20$ & $0.09 \pm 0.04^{\mathrm{a}}$ & $6.94 \pm 0.32^{b}$ & $1030.46 \pm 62.91 \mathrm{bc}$ & $3.97 \pm 1.31^{\mathrm{a}}$ & $0.35 \pm 0.12^{a}$ & $0.99 \pm 0.02^{a}$ \\
\hline & $\mathrm{BH} 80$ & $0.08 \pm 0.04^{a}$ & $7.24 \pm 0.25^{b}$ & $1102.68 \pm 92.00^{c}$ & $3.21 \pm 0.61^{\mathrm{a}}$ & $0.28 \pm 0.04^{\mathrm{a}}$ & $0.99 \pm 0.01^{\mathrm{a}}$ \\
\hline \multirow[t]{4}{*}{ Dec-17 } & BO & $0.06 \pm 0.01^{a}$ & $3.01 \pm 0.24^{\mathrm{a}}$ & $733.42 \pm 30.58^{a}$ & $15.05 \pm 0.09^{a}$ & $0.93 \pm 0.13^{a}$ & $0.98 \pm 0.03^{a}$ \\
\hline & BH5 & $0.07 \pm 0.02^{a}$ & $3.30 \pm 0.18 \mathrm{ab}$ & $780.39 \pm 69.98^{a}$ & $12.60 \pm 0.80^{a}$ & $0.95 \pm 0.03^{a}$ & $0.98 \pm 0.04^{\mathrm{a}}$ \\
\hline & $\mathrm{BH} 20$ & $0.08 \pm 0.01^{a}$ & $3.86 \pm 0.27^{b}$ & $819.21 \pm 122.80^{a}$ & $12.16 \pm 2.36^{a}$ & $0.92 \pm 0.08^{a}$ & $0.98 \pm 0.05^{\mathrm{a}}$ \\
\hline & $\mathrm{BH} 80$ & $0.08 \pm 0.01^{a}$ & $4.04 \pm 0.19^{b}$ & $805.57 \pm 129.43^{a}$ & $11.66 \pm 2.46^{a}$ & $0.90 \pm 0.09^{a}$ & $0.99 \pm 0.01^{\mathrm{a}}$ \\
\hline \multirow[t]{4}{*}{ Mar-18 } & BO & $0.08 \pm 0.01^{a}$ & $3.95 \pm 0.36^{\mathrm{a}}$ & $711.93 \pm 63.01^{\mathrm{a}}$ & $11.87 \pm 1.41^{\mathrm{a}}$ & $0.94 \pm 0.07^{b}$ & $0.99 \pm 0.06^{\mathrm{a}}$ \\
\hline & BH5 & $0.06 \pm 0.01^{a}$ & $4.32 \pm 0.069^{a}$ & $752.32 \pm 65.55^{\mathrm{a}}$ & $12.25 \pm 0.76^{a}$ & $0.85 \pm 0.02^{b}$ & $0.99 \pm 0.01^{\mathrm{a}}$ \\
\hline & $\mathrm{BH} 20$ & $0.08 \pm 0.01^{a}$ & $4.37 \pm 0.13^{a}$ & $809.25 \pm 108.94^{\mathrm{a}}$ & $7.34 \pm 3.05^{a}$ & $0.56 \pm 0.17^{a b}$ & $0.99 \pm 0.01^{\mathrm{a}}$ \\
\hline & $\mathrm{BH} 80$ & $0.08 \pm 0.01^{\mathrm{a}}$ & $4.43 \pm 0.37^{\mathrm{a}}$ & $975.94 \pm 74.84^{\mathrm{a}}$ & $6.16 \pm 1.81^{\mathrm{a}}$ & $0.51 \pm 0.15^{\mathrm{a}}$ & $0.99 \pm 0.02^{\mathrm{a}}$ \\
\hline
\end{tabular}

relative to Bo. In the third season (December 2017), there was a reduction in photosynthetic pigment concentrations for all seedlings, but the seedlings in $\mathrm{BH} 20$ and BH80 treatments showed significant influence $(p<0.05)$ compared to Bo, and there was an increase of $3 \%$ in TC concentrations under BH8O amended seedlings (Fig. 2C).

Likewise, in the fourth season (March 2018), the highest dose of $\mathrm{BC}(\mathrm{BH} 80)$ influenced the TC concentration significantly ( $p$ $<0.05$ ) compared to other levels and an increase of $13 \%$ was observed for BH 80 seedlings as compared to Bo (Fig. 2d). In $B C$ amended seedlings, carotenoids concentration was significantly impacted $(p<$
Tab. 2 - Season-wise biochemical attributes in seedlings treated with different levels of biochar ( $\mathrm{BC})$. (Bo): control soil without hardwood biochar amendment; $\left(\mathrm{BH}_{5}\right)$ : hardwood biochar-amended soil at $5 \mathrm{~g} \mathrm{~kg}^{-1} ;\left(\mathrm{BH}_{20}\right)$ : hardwood biochar-amended soil at $20 \mathrm{~g} \mathrm{~kg}^{-1}$; (BH80): hardwood biochar-amended soil at $80 \mathrm{~g} \mathrm{~kg}^{-1}$. Significant differences $(p<0.05)$ among treatments are shown by different letters. Values are means \pm standard errors $(n=4)$.

\begin{tabular}{|c|c|c|c|c|c|}
\hline 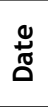 & $\begin{array}{l}\text { Treat- } \\
\text { ments }\end{array}$ & $\underset{\left(\mu \mathrm{g} \mathrm{g}^{-1}\right)}{\operatorname{Amino}}$ & $\begin{array}{l}\text { Ascorbic acid } \\
\qquad\left(\mu g^{-1}\right)\end{array}$ & $\begin{array}{l}\text { Soluble sugar } \\
\qquad\left(\mu \mathrm{g} \mathrm{g}^{-1}\right)\end{array}$ & $\begin{array}{l}\text { Total Soluble } \\
\text { Protein } \\
\left(\mathrm{g} \mathrm{L}^{-1}\right)\end{array}$ \\
\hline \multirow{4}{*}{$\stackrel{N}{\stackrel{5}{5}}$} & B0 & $4.04 \pm 0.38^{a}$ & $19.58 \pm 1.22^{b}$ & $11040.97 \pm 495.12^{a}$ & $0.23 \pm 0.02^{a b}$ \\
\hline & BH5 & $5.17 \pm 0.26^{a b}$ & $19.01 \pm 0.90^{b}$ & $12458.47 \pm 134.26^{b}$ & $0.20 \pm 0.03^{a}$ \\
\hline & $\mathrm{BH} 20$ & $7.01 \pm 0.26^{b}$ & $14.57 \pm 2.28^{b}$ & $12558.13 \pm 76.72^{b}$ & $0.28 \pm 0.04^{b}$ \\
\hline & $\mathrm{BH} 80$ & $8.76 \pm 1.00^{b}$ & $9.52 \pm 1.06^{a}$ & $15049.83 \pm 191.81^{c}$ & $0.40 \pm 0.02^{c}$ \\
\hline \multirow{4}{*}{$\frac{N}{\grave{i}}$} & B0 & $1.00 \pm 0.29^{a}$ & $186.16 \pm 17.36^{b}$ & $24316.80 \pm 3953.43^{a}$ & $0.42 \pm 0.01^{\mathrm{a}}$ \\
\hline & $\mathrm{BH} 5$ & $2.29 \pm 0.15^{b}$ & $124.36 \pm 20.30^{\mathrm{a}}$ & $35241.51 \pm 3130.46^{a}$ & $0.64 \pm 0.01^{b}$ \\
\hline & $\mathrm{BH} 20$ & $2.70 \pm 0.23^{b}$ & $113.50 \pm 4.45^{\mathrm{a}}$ & $35561.35 \pm 6541.47^{\mathrm{a}}$ & $0.69 \pm 0.02^{b}$ \\
\hline & $\mathrm{BH} 80$ & $2.96 \pm 0.28^{b}$ & $130.31 \pm 13.90^{a}$ & $34843.34 \pm 2321.57^{\mathrm{a}}$ & $0.83 \pm 0.01^{c}$ \\
\hline \multirow{4}{*}{$\frac{N}{\dot{u}}$} & B0 & $1.44 \pm 0.35^{\mathrm{a}}$ & $76.84 \pm 6.55^{c}$ & $34623.27 \pm 392.65^{a}$ & $0.16 \pm 0.06^{\mathrm{a}}$ \\
\hline & BH5 & $2.83 \pm 0.52^{a}$ & $41.31 \pm 0.99^{b}$ & $36870.68 \pm 1845.46^{a}$ & $0.16 \pm 0.05^{a}$ \\
\hline & $\mathrm{BH} 20$ & $2.89 \pm 0.67^{a}$ & $7.93 \pm 0.95^{\mathrm{a}}$ & $47086.20 \pm 1037.59^{b}$ & $0.17 \pm 0.04^{\mathrm{a}}$ \\
\hline & $\mathrm{BH} 80$ & $2.64 \pm 0.52^{a}$ & $6.17 \pm 0.24^{a}$ & $51801.72 \pm 2485.96^{b}$ & $0.17 \pm 0.03^{a}$ \\
\hline \multirow{4}{*}{$\sum_{\frac{1}{i}}^{\infty}$} & B0 & $1.32 \pm 0.47^{\mathrm{a}}$ & $37.74 \pm 0.50^{c}$ & $36000.00 \pm 1076.49^{a}$ & $0.17 \pm 0.04^{\mathrm{a}}$ \\
\hline & BH5 & $1.32 \pm 0.47^{\mathrm{a}}$ & $17.02 \pm 1.12^{b}$ & $37028.45 \pm 486.15^{a}$ & $0.17 \pm 0.03^{a}$ \\
\hline & $\mathrm{BH} 20$ & $1.51 \pm 0.38^{a}$ & $5.08 \pm 0.14^{a}$ & $37045.97 \pm 521.88^{a}$ & $0.18 \pm 0.04^{\mathrm{a}}$ \\
\hline & $\mathrm{BH} 80$ & $2.02 \pm 0.45^{\mathrm{a}}$ & $4.61 \pm 0.16^{\mathrm{a}}$ & $37568.96 \pm 180.55^{a}$ & $0.20 \pm 0.02^{\mathrm{a}}$ \\
\hline
\end{tabular}

0.05) in the first season. Whereas in the third and fourth seasons, none of the $B C$ rates influenced the concentration of carotenoids compared with Bo.

The values of photosynthetic parameters such as initial slope (a), maximum photosynthetic rate (Pn-max), light saturation point (LSP), light compensation point (LCP), rate of dark respiration (Rd), and adjusted $R^{2}$ are depicted in Tab. 1. Photosynthetic rate (Pn-max) increased with a rise in gradient (PPFD), as shown in Fig. 3 and reached LSP, while with further increase in gradient, Pn started to decrease due to photo-inhibition. Based on the results of the modified model of rectangular hyperbola, Pn-max, and LSP both were decreased while LCP was increased (Tab. 1). In the first season, $B C$ amended seedlings showed significantly $(\mathrm{p}<0.05)$ higher $\mathrm{Pn}$ max values $\left(5.42,6.32\right.$, and $6.72 \mathrm{CO}_{2} \mu \mathrm{mol}$ $\mathrm{m}^{-2} \mathrm{~s}^{-1}$ for $\mathrm{BH}_{5}, \mathrm{BH}_{2} \mathrm{O}$, and $\mathrm{BH} 8 \mathrm{O}$, respectively) compared to $\mathrm{Bo}\left(3.48 \mathrm{CO}_{2} \mu \mathrm{mol} \mathrm{m}{ }^{-2}\right.$ $\left.\mathrm{s}^{-1}\right)$. During the second season, seedlings under $\mathrm{BH}_{2} \mathrm{O}$ and $\mathrm{BH} 8 \mathrm{O}$, the $\mathrm{Pn}$-max values (6.94 and $7.24 \mathrm{CO}_{2} \mu \mathrm{mol} \mathrm{m}^{-2} \mathrm{~s}^{-1}$, respectively) were significantly higher compared to $\mathrm{Bo}$ and $\mathrm{BH}_{5}$ (Tab. 1). A similar trend was noticed for all $B C$ amended seedlings in the third season, when a reduction in the Pnmax range for all amended seedlings compared to the previous season was recorded. Nevertheless, BC altered seedlings, especially $\mathrm{BH} 2 \mathrm{O}$ and $\mathrm{BH} 8 \mathrm{O}$, showed significantly higher Pn-max values (3.86 and 4.04

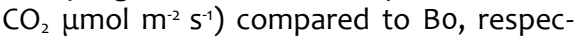
tively. During the fourth season, no significant differences were noticed under the $B C$ treated and Bo seedlings for Pn-max. Additionally, conductance to $\mathrm{H}_{2} \mathrm{O}$ (Cond), inter- 
Fig. 3 - Response of net photosynthetic rate at different photosynthetic photon flux density levels (PPFD) under different BH levels. (Bo): control soil without hardwood biochar amendment; ( $\left.\mathrm{BH}_{5}\right)$ : hardwood biochar-amended soil at $5 \mathrm{~g} \mathrm{~kg}^{-1} ;\left(\mathrm{BH}_{2} \mathrm{O}\right)$ : hardwood biocharamended soil at $20 \mathrm{~g} \mathrm{~kg}^{-1}$; (BH80): hardwood biocharamended soil at $80 \mathrm{~g} \mathrm{~kg}^{-1}$, respectively. (a): $1^{\text {st }}$ season (June 2017); (b): $2^{\text {nd }}$ season (September 2017); (c): $3^{\text {rd }}$ season (December 2017);

(d): $4^{\text {th }}$ season (March 2018). Vertical bars represent the standard error of the mean $(n=3)$.
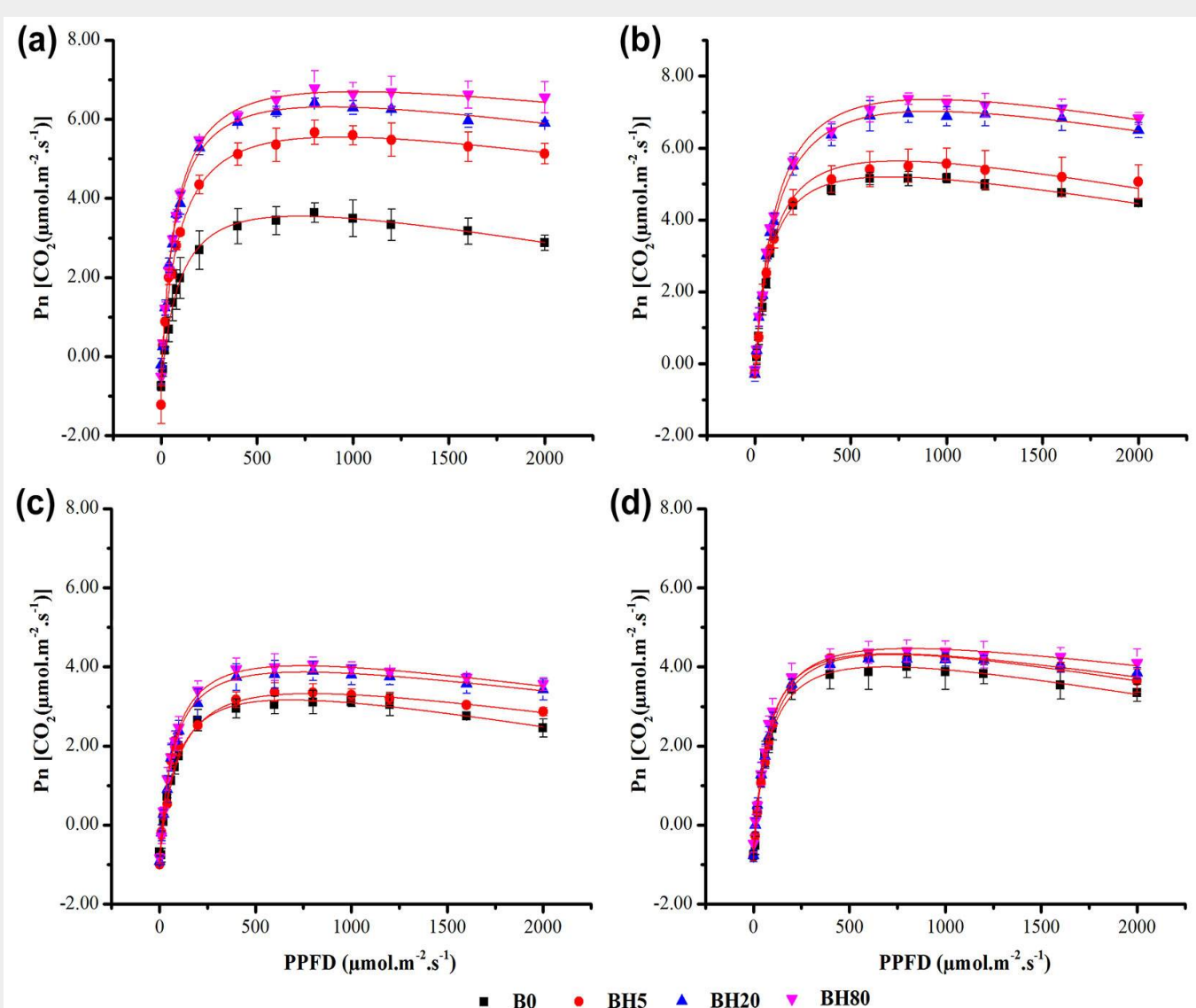

cellular $\mathrm{CO}_{2}$ concentration $(\mathrm{Cl})$, and transpiration rate (Trmmol) were also recorded at different PPFD, where greater Cond and Trmmol increased with $\mathrm{Pn}$ and decreased $\mathrm{Cl}$ (see Fig. S1, Fig. S2, and Fig. S3 in Supplementary material).

\section{Influence of BC on biochemical attributes}

The effect of $B C$ as soil amendment on the biochemical attributes of $F$. hodginsii seedlings is reported in Tab. 2. Seedlings showed significant differences $(p<0.05)$ for amino acid under $\mathrm{BH} 2 \mathrm{O}$ and $\mathrm{BH} 8 \mathrm{O}$ amendments in the first two consecutive seasons, compared to Bo. Nevertheless, none of the $B C$ doses influenced amino acid concentrations during the final two seasons (Tab. 2). Ascorbic acid concentrations decreased significantly $(p<0.05)$ by increasing the level of $\mathrm{BC}$. During the whole study period, $\mathrm{BH} 2 \mathrm{O}$ and $\mathrm{BH} 8 \mathrm{O}$ treated seedlings showed significant differences over Bo (Tab. 2). Likewise, compared with $\mathrm{Bo}$, concentrations of soluble sugar under $\mathrm{BH} 2 \mathrm{O}$ and $\mathrm{BH} 80$ amended seedlings were significantly higher $(p<0.05)$ in the first and third seasons (June and December 2017). Total soluble protein (TSP) concentrations were influenced significantly $(\mathrm{p}<$ 0.05 ) for all $\mathrm{BH}$ amended seedlings in the second season. However, during the last two seasons, the addition of $B C$ did not affect TSP concentrations in comparison with Bo (Tab. 2). (a) $\square$ Height (cm)

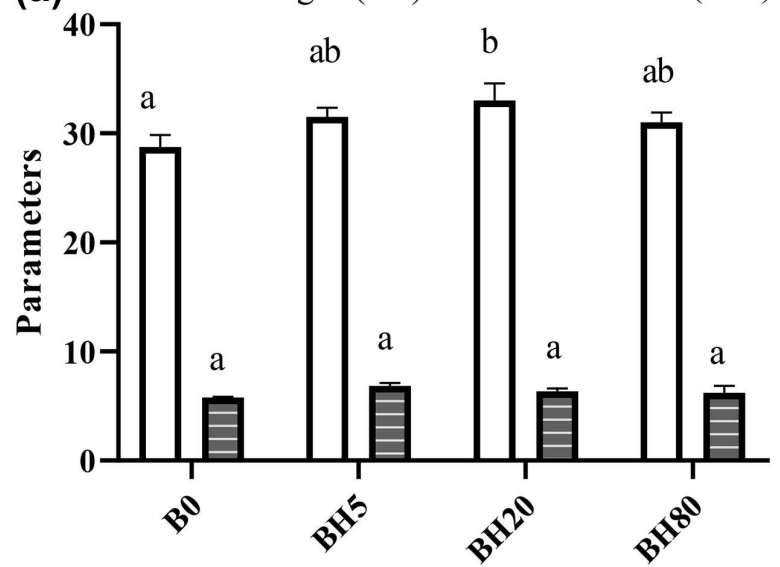

(b) $\square$ Fresh Weight (g) Dry Weight (g)

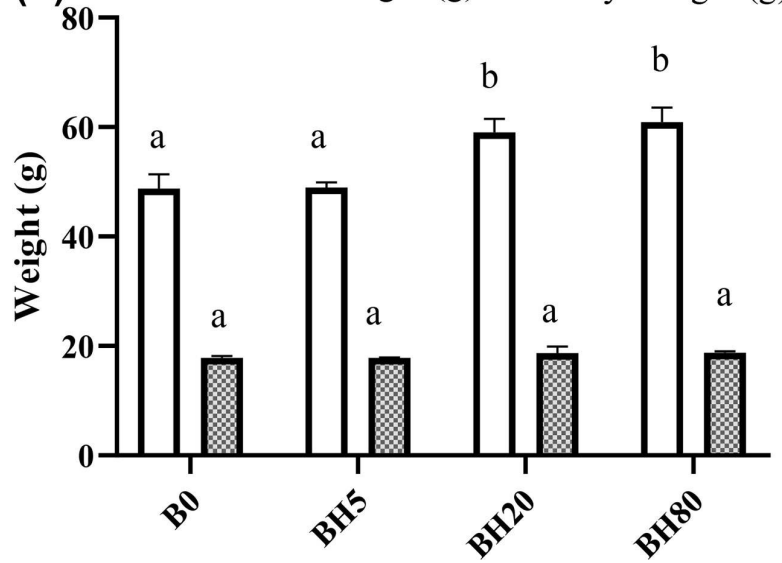

Treatments
Fig. 4 - (a) Height and diameter (b) biomass and dry weight of seedlings treated with different levels of hardwood biochar. (Bo): control soil without hardwood biochar amendment; (BH5): hardwood biochar-amended soil at $5 \mathrm{~g} \mathrm{~kg}^{-1} ;$ (BH2O): hardwood biocharamended soil at $20 \mathrm{~g}$ $\mathrm{kg}^{-1}$; (BH80): hardwood biocharamended soil at $80 \mathrm{~g}$ $\mathrm{kg}^{-1}$, respectively. A significant difference ( $p<0.05$ ) among treatments is indicated by different letters. Vertical bars represent the standard error of the mean $(n=4)$. 
Influence of $B C$ on plant morphological features and plant biomass

In terms of morphological attributes, seedlings of $F$. hodginsii established under $\mathrm{BH}_{20} \mathrm{O}$ treatment significantly $(\mathrm{p}<0.05)$ in fluenced the plant height compared to Bo. However, no significant differences were observed for seedling's diameter, under varying levels of the BC (Fig. 4a). Compared to $\mathrm{Bo}$, the total biomass of seedlings treated with $\mathrm{BH} 20(21 \%)$ and $\mathrm{BH} 80(25 \%)$ was significantly higher. Similarly, seedlings treated with $\mathrm{BH} 8 \mathrm{O}, \mathrm{BH}_{2} \mathrm{O}$, and $\mathrm{BH}_{5}$ en hanced the plant dry weight (5.38\%, $4.79 \%$, and $0.154 \%$ respectively) over Bo with no significant differences (Fig. 4b).

\section{Discussion}

The amendment of $B C$ has been sug gested to enhance soil nutrients dynamics, quality, and plant productivity (Du et al. 2018). In this study, under $B C$ addition, soi physicochemical properties were improved after one year in the glasshouse pot experiment. $\mathrm{BC}$ incorporation influenced the soi $\mathrm{pH}$ significantly $(\mathrm{p}<0.05)$ under $\mathrm{BH}_{2} \mathrm{O}$ and $\mathrm{BH} 80$ amendments. The great liming effect of $B C$ has also been reported in previous studies on acidic soils. In this study, the rise in soil $\mathrm{pH}$ improved the availability of nutri ents, particularly $\mathrm{P}$ and $\mathrm{K}$, which is consis tent with previous findings (Bu et al. 2020). BC amendment significantly affected the TN and TC of soil by increasing the level, which is attributed to the presence of $N$ and $\mathrm{C}$ contents in the $\mathrm{BC}$ feedstock. Biederman et al. (2017) stated that increased TN retention in $B C$ amended soil is due to nitrates recycling because of the higher availability of $C$. Soil $P$ and $K$ availability were significantly improved under higher doses of $\mathrm{BC}\left(\mathrm{BH}_{2} \mathrm{O}\right.$ and $\left.\mathrm{BH} 8 \mathrm{O}\right)$, due to the greater concentrations of available $P$ and $K$ in the $B C$ being released into acidic soils (Fig. 1). Prendergast-Miller et al. (2014) showed that $B C$ particles not only hold the soil $\mathrm{N}$ in the form of nitrate but also supply $\mathrm{P}$ to the soil and plant, as observed in this study. Moreover, Agegnehu et al. (2015) stated that ash contents in $\mathrm{BC}$ alleviate the soil $\mathrm{pH}$ which improves the availability of the nutrients ( $\mathrm{K}, \mathrm{Ca}$, and $\mathrm{Mg}$ ).

Biochemical leaf traits and photosynthet ic pigments are the key indicators of plant metabolism that are mainly influenced by the availability of resources (nutrients) and environmental conditions. BC increases the absorption of nutrients by enhancing the physiological state of the entire plant (Backer et al. 2017). Overall, the seedlings treated with $\mathrm{BC}$ showed higher concentration of amino acids in the first season, whereas TSP concentrations were greater in the second season. One possible reason for this rise in amino acid concentration was owing to the addition of NPK fertilizer applied to all seedlings in the first season. Indeed, previous studies on BCs proved that $B C$ efficacy can be improved if combined with fertilizers. Greater concentrations of TSP at the second season under BC amended seedlings are attributed to allocations of nutrients. The highest photosynthetic pigment concentrations (Fig. 2b) under $B C$ treated seedlings indicates the $N$ status of plants compared to Bo, as confirmed in previous studies (Mastalerczuk et al. 2017). Besides, the growing season of this conifer is July-September where plants produce higher concentrations of biochemicals. Similar to our findings, Gezelius \& Hallen (1980) revealed that the concentration of needle TSP in Scots pine started to decline in April and then increase in July. In addition, in the current research, seedlings were able to grow under normal conditions. However, there were plenty of differences in air temperature in four seasons (Fig. S4 in Supplementary material). Zemanova et al. (2017) stated that both amino acids and TSP are environmentally dependent factors as their concentrations vary with fluctuation in temperature, and the plant produces high concentrations of amino acids under favorable conditions.

The variations in concentration of soluble sugars and ascorbic acids were also due to temperature fluctuations in various seasons. Ascorbic acid is an antioxidant molecule which plays a key role in the mechanisms of defense against environmental stress due to temperature variations (Fig. $\mathrm{S}_{4}$ in Supplementary material). The most effective function of ascorbic acid is to protect lipids and proteins against salinity or oxidative adverse reactions caused by drought (Naz et al. 2016). Plants exposed to environmental stress have the tendency to accumulate osmotic substances in cells (Kazemi et al. 2010), such as proline, soluble sugar, ascorbic acid, and various osmoprotectants. Besides, the application of BC to the soil can also substantially alters the soil structure and field capability and exhibit the antioxidant activity by decreasing the membrane permeability and contents of ascorbic acid. BC incorporation at higher levels reduced the concentrations of ascorbic acid, which is in accordance with previous studies (Wang et al. 2014).

Based on biochemical and molecular research, soluble sugars play a key role in controlling plant metabolism. In our experiment, BC amended seedlings accumulated more soluble sugars at first and third season compared to Bo. Increased concentrations of soluble sugars enable plants to cope with cold stress in winters (Shao et al. 2008). Similar to our findings, Yuanyuan et al. (2010) confirmed that soluble sugars concentrations under low-temperature (winters) increase (Dec-17) and decrease (Jun-17) in summers.

Several environmental factors affect $\mathrm{Pn}$, including light, temperature, air $\mathrm{CO}_{2}$ concentration, water supply, the vapor pressure differential between leaves and air, soil fertility, salinity, toxins, applied chemicals, insects, diseases, and various interactions between them. Among them, light and temperature are the most influential factors involved in species survival, devel- opment, and reproduction. Their responses usually cause physiological changes, which are decisive for assimilating $\mathrm{CO}_{2}$ and optimizing gas exchange (Cai et al. 2020). In the current study, variations in $\mathrm{Pn}$ and photosynthetic pigments in different seasons might be due to variation in temperature and daylight (Sarauer \& Coleman 2018). For instance, all the $B C$ treated seedlings enhanced their photosynthetic pigments and Pn-max during the first season (Fig. 2, Tab. 1). The addition of $B C$ to soil has been sug gested as a way to increase soil water holding capacity, nutrient retention, and soil aeration and respiration (Shaaban et al. 2018). Higher concentrations of photosynthetic pigment under $B C$ treated seedlings, particularly in the first season, was due to the availability of essential nutrients. As stated before, NPK fertilizer was applied to all seedlings and the combined application of $\mathrm{BC}$ with fertilizer improved the concentration of photosynthetic pigments and thus Pn-max. Chen et al. (2018) demonstrated that $\mathrm{Pn}$ is highly dependent on the concentration of photosynthetic pigments. Another possible reason for the improved $P n$ in $B C$ amended seedlings might be the presence of available $P$. The $P$ availability through $B C$ is likely to improve the $P n$ in red soil, owing to its vital role in the regulation of electron transport (Xu et al. 2015).

The above mentioned beneficial effects of soil BC amendments together lead to a significant increase in plant physiological and biochemical efficiency. The use of $B C$ in vineyards enhanced the soil water content and then improved the plant supply of water and Pn activity in the leaves of Vitis vinifera L. (Baronti et al. 2014). Plant water status plays an important role in plant growth and photosynthetic efficiency. Our research confirmed the findings that the addition of $B C$ to soil increased the availability of water, which is responsible for increasing Pn and Cond. A similar impact of $B C$ on the availability of soil water has also been determined by previous studies ( $\mathrm{Abi}$ deen et al. 2020, Kammann et al. 2011). However, at the final harvest, seedlings treated with $\mathrm{BH} 80$ showed a noticeable influence on photosynthetic pigments (TC) but no effect on Pn-max over Bo.

During the third and fourth seasons, suppression in Pn-max in plants was caused by the combined effects of daylight and temperature (Fig. $\mathrm{S}_{4}$ in Supplementary material). As reported in previous studies, low temperature inhibits Pn by reducing the activity of Calvin cycle enzymes (Weng et al. 2005), whereas the absorption of light energy beyond that which could be used in low-temperature $\mathrm{Pn}$ induces photo-inhibition of Photosystem II (PSII - Streb et al. 1998). Similar to our findings, various studies have seen fluctuations in the Pn capacity of other conifers (spruce and pine species) and demonstrated that changes in Pn capability are closely related to seasonal variations in air temperature (Lundmark et al. 1988, Weng et al. 2005). Moreover, the 
activity of Ribulose-1,5-biphosphate carboxylase (Rubisco), the enzyme responsible for the fixation of $\mathrm{CO}_{2}$ in chloroplasts, varies with the season, with significantly higher activity during summer than in winter (Naidu \& Swamy 1995). A strong correlation has been reported in several cases between Rubisco activity and TSP concentration in leaves (Weng et al. 2005). In addition, chlorophyll concentrations have been shown to decrease in winter, under low temperature and short-day conditions (Chen et al. 2018, Tarin et al. 2020). Therefore, the observed decrease in Pn-max during the third season may also be associated with a decrease in chlorophyll concentration.

The process of acclimatization to high-irradiance environments is very complex, involving both water and nutrient availability (De Carvalho Goncalves et al. 2005). The physiological activity of $F$. hodginsii plants exposed to various PPFD in this study indicates that their $\mathrm{Pn}$ apparatus is more effective when subjected to medium light intensity conditions, between 700 and 1100 $\mu \mathrm{mol} \mathrm{m} \mathrm{m}^{-2} \mathrm{~s}^{-1}$ (Tab. 1). The rate of Pn also increases rapidly with an increase in incidental PPFD before the plateau is reached. This initial linear relationship reflects the photochemical efficiency of plants, i.e., the ability to absorb light (LUE). The Pn rate increases linearly with increased irradiance since $\mathrm{CO}_{2}$ fixation and electron transport processes are proportional to the photons captured (Sheu \& Lin 1999). Therefore, these findings suggest that, during $F$. hodginsii early growth period, intermediate light conditions are more suitable for this species to achieve higher rates of $C$ assimilation and accumulation of biomass.

In the short term (days to weeks) the environmental conditions affect Pn by controlling stomatal conductance and photosynthetic ability of mesophylls. We found great differences in Cond and Trmmol among $B C$ applications in diverse seasons except for $\mathrm{Ci}$ (Fig. S1, Fig. S2, Fig. S3 in supplementary material). The increase in $\mathrm{Ci}$ indicates a reduction in the activity of $\mathrm{CO}_{2}$ assimilation, with limited carboxylation efficiency (Farquhar \& Sharkey 1982). It seems appropriate to refer to $\mathrm{Ci}$ as an effective concentration of $\mathrm{CO}_{2}$ controlling stomata (Mansfield et al. 1990). However, in the current study, all the seedlings received the same amount of water. A sufficient supply of water is an advantage in terms of limited response to $\mathrm{Ci}$, as this restricts the reluctance of the stomata to limit the supply of $\mathrm{CO}_{2}$ to $\mathrm{Pn}$. However, under minimal water supply, the priority of the plant shifts from maximizing assimilation to limiting transpiration while retaining as much assimilation as possible (De Assis Gomes et al. 2004).

Numerous BC studies have demonstrated beneficial effects on biomass increase (Choi et al. 2018, Bu et al. 2020). Likewise, we also found a positive influence of $B C$ on the biomass of $F$. hodginsii particularly un- der $\mathrm{BH} 2 \mathrm{O}$ and $\mathrm{BH} 80$ amendments. $\mathrm{BC}$ supplements to soil provide greater water availability, increase nutrient absorption, provide better conditions for the synthesis of organic solutes, and minimize oxidative stress through high water performance (Paneque et al. 2016). The improved photosynthetic performance of seedlings resulted in a greater capacity to accumulate biomass. This improvement in biomass was collectively associated with increased physiological parameters particularly $\mathrm{Pn}$ and the availability of nutrients ( $\mathrm{P}$ and $\mathrm{K}$ ) because of the rise in the soil pH. Altogether, these improvements in soil quality lead to a major enhancement of the physiological status of seedlings and thus to their biomass production. Nonetheless, abiotic factors (air temperature, light, water, $\mathrm{CO}_{2}$, and nutrients) and physiologically mediated factors (Cond and Trmmol) may have a significant effect on this process (De Carvalho Goncalves et al. 2005). Our findings are in line with previous authors who suggested that $B C$ containing high amount of of available $\mathrm{P}$, can have a positive effect on tree seedling growth (Pluchon et al. 2014). Makoto et al. (2011) also demonstrated that BC significantly contributed to the amelioration of $P$ availability and water availability for pine seedlings.

\section{Conclusions}

The findings of the present research suggest that $\mathrm{BH}$ amendments can be recommended as soil ameliorants into acidic soil. The addition of $\mathrm{BH} 2 \mathrm{O}$ and $\mathrm{BH} 80$ to red soil had a significantly positive impact on the biomass ( $21 \%$ and $25 \%$, respectively) of $\mathrm{F}$. hodginsii. BC supplements to soil provided increased nutrients concentrations, better conditions for the synthesis of photosynthetic pigments, and gas exchange attributes. Altogether such improvement of soil quality contributed to a significant enhancement of the physiological status of plants, thereby increasing the biomass of $F$. Hodginsii seedlings. Besides, it could open up the possibility of sequestering $\mathrm{CO}_{2}$ and generating higher wood productivity and high-quality biomass on degraded soils in China. As BC effects may vary across different soil types and plant species, we recommend to accurately consider soil pH and $\mathrm{N}$ requirements of species selected for maximizing the achievement of BC-based restoration projects. In compliance with the present study, further research is needed on older trees with much slower growth considering the interaction between soil microbial community and soil physiochemical properties to confirm the outcomes of these pot trials.

\section{Acknowledgments}

This work was supported by Science and Technology Major Projects of Fujian Province [2018NZ0001-1] and Fujian Seedling Science and Technology Research Project, P. R. China.

\section{References}

Abideen Z, Koyro H-W, Huchzermeyer B, Bilquees GUL, Khan MA (2020). Impact of a biochar or a biochar-compost mixture on water relation, nutrient uptake and photosynthesis of Phragmites karka. Pedosphere 30 (4): 466-477. doi: 10.1016/S1002-0160(17)60362-X

Agegnehu G, Bass AM, Nelson PN, Muirhead B, Wright G, Bird MI (2015). Biochar and biocharcompost as soil amendments: effects on peanut yield, soil properties and greenhouse gas emissions in tropical North Queensland, Australia. Agriculture, Ecosystems and Environment 213: 72-85. - doi: 10.1016/j.agee.2015.07. 027

Anyanwu IN, Alo MN, Onyekwere AM, Crosse JD, Nworie O, Chamba EB (2018). Influence of biochar aged in acidic soil on ecosystem engineers and two tropical agricultural plants. Ecotoxicology and Environmental Safety 153: 116-126. doi: 10.1016/j.ecoenv.2018.02.005

Backer RGM, Saeed W, Seguin P, Smith DL (2017). Root traits and nitrogen fertilizer recovery efficiency of corn grown in biochar-amended soil under greenhouse conditions. Plant and Soil 415: 1-2.): 465-477. - doi: 10.1007/s11104-0173180-6

Baronti S, Vaccari FP, Miglietta F, Calzolari C, Lugato E, Orlandini S, Pini R, Zulian C, Genesio L (2014). Impact of biochar application on plant water relations in Vitis vinifera (L.). European Journal of Agronomy 53: 38-44. - doi: 10.1016/j. eja.2013.11.003

Biederman LA, Phelps J, Ross BJ, Polzin M, Harpole WS (2017). Biochar and manure alter few aspects of prairie development: a field test. Agriculture, Ecosystems and Environment 236: 78-87. - doi: 10.1016/j.agee.2016.11.016

Bradford MM (1976). A rapid and sensitive method for the quantitation of microgram quantities of protein utilizing the principle of protein-dye binding. Analytical Biochemistry 72: 248-254. doi: 10.1016/0003-2697(76)90527-3

Bu X, Xue J, Wu Y, Ma W (2020). Effect of biochar on seed germination and seedling growth of Robinia pseudoacacia L. in karst calcareous soils. Communications in Soil Science and Plant Analysis 51 (3): 352-363. - doi: 10.1080/00103624. 2019.1709484

Cai YQ, Tarin MWK, Fan LL, Xie DJ, Rong JD, He TY, Chen LG, Zheng YS (2020). Responses of photosynthesis, chloroplast ultrastructure, and antioxidant system of Morinda officinalis how. to exogenous 2,4-epibrassinolide treatments under high temperature stress. Applied Ecology and Environmental Research 18: 39814004. - doi: 10.15666/aeer/1803_39814004 Cakmak I, Horst WJ (1991). Effect of aluminium on lipid peroxidation, superoxide dismutase, catalase, and peroxidase activities in root tips of soybean (Glycine max). Physiologia Plantarum 83 (3): 463-468. - doi: 10.1111/j.1399-3054.19 91.tboo121.x

Chen L, Lai J, He T, Rong J, Tarin MWK, Zheng Y (2018). Differences in photosynthesis of variegated temple bamboo leaves with various levels of variegation are related to chlorophyll biosynthesis and chloroplast development. Journal of the American Society for Horticultural Science 143 (2): 144-153. - doi: 10.21273/ JASHSO4359-18 
Choi D, Makoto K, Quoreshi AM, Qu L (2009). Seed germination and seedling physiology of Larix kaempferi and Pinus densiflora in seedbeds with charcoal and elevated $\mathrm{CO}_{2}$. Landscape and Ecological Engineering 5 (2): 107-113. - doi: 10.1007/s11355-009-0072-9

Choi HS, Zhao Y, Dou H, Cai X, Gu M, Yu F (2018). Effects of biochar mixtures with pine-bark based substrates on growth and development of horticultural crops. Horticulture Environ ment and Biotechnology 59 (3): 345-354. - doi: 10.1007/s13580-018-0035-x

De Assis Gomes MDM, Magalhães Andrade Lagôa AM, Medina CL, Machado EC, Machado MA (2004). Interactions between leaf wate potential, stomatal conductance and abscisic acid content of orange trees submitted to drought stress. Brazilian Journal of Plant Physiology 16 (3): 155-161. - doi: 10.1590/s1677-04202 004000300005

De Carvalho Goncalves JF, De Sousa Barreto DC, Dos Santos UM, Fernandes AV, Barbosa Sampaio PDT, Buckeridge MS (2005). Growth, photosynthesis and stress indicators in young rosewood plants (Aniba rosaeodora Ducke) unde different light intensities. Brazilian Journal of Plant Physiology 17: 325-334. - doi: 10.1590/s167 7-04202005000300007

Du Z, Xiao Y, Qi X, Liu Y, Fan X, Li Z (2018). Peanut-shell biochar and biogas slurry improve soil properties in the North China plain: a four-year field study. Scientific Reports 8 (1): 1-9. - doi: 10.1038/s41598-018-31942-0

Farquhar GD, Sharkey TD (1982). Stomatal conductance and photosynthesis. Annual Review of Plant Physiology 33 (1): 317-345. - doi: 10.1146/ annurev.pp.33.060182.001533

Gezelius K, Hallen M (1980). Seasonal variation in ribulose bisphosphate carboxylase activity in Pinus silvestris. Physiologia Plantarum 48 (1) 88-98. - doi: 10.1111/j.1399-3054.1980.tbo3224.x Haefele SM, Konboon Y, Wongboon W, Amarante S, Maarifat AA, Pfeiffer EM, Knoblauch C (2011). Effects and fate of biochar from rice residues in rice-based systems. Field Crops Research 121 (3): 430-440. - doi: 10.1016/j.fcr.2011. 01.014

Haynes RJ, Mokolobate MS (2001). Amelioration of $\mathrm{Al}$ toxicity and $\mathrm{P}$ deficiency in acid soils by additions of organic residues: a critical review of the phenomenon and the mechanisms in volved. Nutrient Cycling in Agroecosystems 59 (1): 47-63. - doi: 10.1023/A:1009823600950 Kammann $\mathrm{Cl}$, Linsel S, Göling JW, Koyro H-W (2011). Influence of biochar on drought tolerance of Chenopodium quinoa Willd and on soilplant relations. Plant and Soil 345 (1-2): 195-210. - doi: 10.1007/s11104-011-0771-5

Kazemi N, Khavari-Nejad RA, Fahimi H, Saadatmand S, Nejad-Sattari T (2010). Effects of exogenous salicylic acid and nitric oxide on lipid peroxidation and antioxidant enzyme activities in leaves of Brassica napus L. under nickel stress. Scientia Horticulturae 126 (3): 402-407. doi: 10.1016/j.scienta.2010.07.037

Keller T, Schwager H (1977). Air pollution and as corbic acid. European Journal of Forest Pathology 7 (6): 338-350. - doi: 10.1111/j.1439-0329.19 77.tboo603.x

Levesque $\mathrm{V}$, Rochette $\mathrm{P}$, Ziadi $\mathrm{N}$, Dorais $\mathrm{M}, \mathrm{An}$ toun $\mathrm{H}$ (2018). Mitigation of $\mathrm{CO}_{2}, \mathrm{CH}_{4}$ and $\mathrm{N}_{2} \mathrm{O}$ from a fertigated horticultural growing medium amended with biochars and a compost. Applied Soil Ecology 126: 129-139. - doi: 10.1016/ j.apsoil.2018.02.021

Lichtenthaler HK (1987). Chlorophylls and carotenoids: pigments of photosynthetic biomembranes. In: "Methods in Enzymology". Elsevier, Amsterdam, Netherlands, vol. 148, pp. 350-382. - doi: 10.1016/0076-6879(87)48036-1

Lundmark T, Hedén J, Hällgren J-E (1988). Recovery from winter depression of photosynthesis in pine and spruce. Trees 2 (2): 110-114. - doi: 10.1007/BF00196757

Lusiba S, Odhiambo J, Ogola J (2018). Growth, yield and water use efficiency of chickpea ( $\mathrm{Ci}$ cer arietinum): response to biochar and phosphorus fertilizer application. Archives of Agronomy and Soil Science 64 (6): 819-833. - doi: 10.1080/03650340.2017.1407027

Makoto K, Hirobe M, DeLuca TH, Bryanin SV, Procopchuk VF, Koike T (2011). Effects of firederived charcoal on soil properties and seedling regeneration in a recently burned Larix gmelinii/Pinus sylvestris forest. Journal of Soils and Sediments 11 (8): 1317-1322. - doi: 10.1007/ s11368-011-0424-6

Mansfield TA, Hetherington AM, Atkinson $\mathrm{CJ}$ (1990). Some current aspects of stomatal physiology. Annual Review of Plant Biology 41 (1): 55-75. - doi: 10.1146/annurev.pp.41.060190.0004

Mastalerczuk G, Borawska-Jarmulowicz B, Kalaji HM, Dabrowski P, Paderewski J (2017). Gas-exchange parameters and morphological features of festulolium (Festulolium braunii K. Richert A. Camus) in response to nitrogen dosage. Photosynthetica 55 (1): 20-30. - doi: 10.1007 /s11099-016-0665-0

Naidu CV, Swamy PM (1995). Seasonal variation in ribulose 1,5-bisphosphate carboxylase activity and its relationship with leaf protein content and net photosynthetic rate in tropical deciduous tree species. Photosynthetica 31 (1): 85-90. Naz H, Akram NA, Ashraf M (2016). Impact of ascorbic acid on growth and some physiological attributes of cucumber (Cucumis sativus) plants under water-deficit conditions. Pakistan Journal of Botany 48 (3): 877-883. [online] URL: http://www.pakbs.org/pjbot/PDFs/48(3)/05.pdf Nobile C, Denier J, Houben D (2019). Linking biochar properties to biomass of basil, lettuce and pansy cultivated in growing media. Scientia Horticulturae. 261: 109001. - doi: 10.1016/j.scien ta.2019.109001

Omil B, Pineiro V, Merino A (2013). Soil and tree responses to the application of wood ash containing charcoal in two soils with contrasting properties. Forest Ecology and Management 295: 199-212. - doi: 10.1016/j.foreco.2013.01.024 Paneque M, Jose M, Franco-Navarro JD, Colmenero-Flores JM, Knicker H (2016). Effect of biochar amendment on morphology, productivity and water relations of sunflower plants under non-irrigation conditions. Catena 147: 280-287. - doi: 10.1016/j.catena.2016.07.037

Pansu M, Gautheyrou J (2007). Handbook of soil analysis: mineralogical, organic and inorganic methods. Springer Science and Business Media, Berlin-Heidelberg-New York, pp. 993. [online] URL: http://books.google.com/books?id=W7Ko $x Z \times 7 N_{3} Y C$
Pluchon N, Gundale MJ, Nilsson M, Kardol P, Wardle DA (2014). Stimulation of boreal tree seedling growth by wood-derived charcoal: ef fects of charcoal properties, seedling species and soil fertility. Functional Ecology 28 (3): 766 775. - doi: 10.1111/1365-2435.12221

Prendergast-Miller MT, Duvall M, Sohi SP (2014). Biochar-root interactions are mediated by biochar nutrient content and impacts on soil nutrient availability. European Journal of Soil Science 65 (1): 173-185. - doi: 10.1111/ejss.12079

Sarauer JL, Coleman MD (2018). Biochar as a growing media component for containerized production of Douglas-fir. Canadian Journal of Forest Research 48 (5): 581-588. - doi: 10.1139/ cjfr-2017-0415

Shaaban M, Van Zwieten L, Bashir S, Younas A Núñez-Delgado A, Chhajro MA, Kubar KA, Ali U, Rana MS, Mehmood MA (2018). A concise review of biochar application to agricultural soils to improve soil conditions and fight pollution. Journal of Environmental Management 228: 429-440. - doi: 10.1016/j.jenvman.2018.09.006 Shao H-B, Chu L-Y, Jaleel CA, Zhao C-X (2008). Water-deficit stress-induced anatomical changes in higher plants. Comptes Rendus Biologies 331 (3): 215-225. - doi: 10.1016/j.crvi.2008.01.002 Sheu BH, Lin CK (1999). Photosynthetic response of seedlings of the sub-tropical tree Schima superba with exposure to elevated carbon diox ide and temperature. Environmental and Experimental Botany 41 (1): 57-65. - doi: 10.1016/Soog 8-8472(98)00048-3

Streb P, Shang W, Feierabend J, Bligny R (1998) Divergent strategies of photoprotection in high-mountain plants. Planta 207 (2): 313-324. doi: $10.1007 / 5004250050488$

Tarin MWK, Lili F, Lu S, Jinli L, Jingwen L, Zhiwen $\mathrm{D}$, Lingyan $\mathrm{C}$, Tianyou $\mathrm{H}$, Rong J, Zheng $\mathrm{Y}$ (2020). Rice straw biochar impact on physiological and biochemical attributes of Fokienia hodginsii in acidic soil. Scandinavian Journal of Forest Research 35 (1-2): 59-68. - doi: 10.1080/028 27581.2020 .1731591

Thomas SC, Frye S, Gale N, Garmon M, Launchbury R, Machado N, Melamed S, Murray J, Petroff A, Winsborough C (2013). Biochar mitigates negative effects of salt additions on two herbaceous plant species. Journal of Environmental Management 129: 62-68. - doi: 10.1016/j. jenvman.2013.05.057

Uzoma KC, Inoue M, Andry H, Fujimaki H, Zahoor A, Nishihara E (2011). Effect of cow manure biochar on maize productivity under sandy soil condition. Soil Use and Management 27 (2) 205-212. - doi: 10.1111/j.1475-2743.2011.00340.x Videgain-Marco M, Marco-Montori P, Martí-Dalmau C, Jaizme-Vega MC, Manyà-Cervelló JJ, García-Ramos FJ (2020). Effects of biochar application in a sorghum crop under greenhouse conditions: growth parameters and physicochemical fertility. Agronomy 10 (1): 104. - doi: 10.3390/agronomy10010104

Wang Y, Pan F, Wang G, Zhang G, Wang Y, Chen $X$, Mao $Z$ (2014). Effects of biochar on photosynthesis and antioxidative system of Malus hupehensis Rehd. seedlings under replant conditions. Scientia Horticulturae 175: 9-15. - doi: 10.1016/j.scienta.2014.05.029

Watanabe FS, Olsen SR (1965). Test of an ascorbic acid method for determining phosphorus in 
water and $\mathrm{NaHCO}_{3}$ extracts from soil. Soil Science Society of America Journal 29 (6): 677678. - doi: 10.2136/sssaj1965.036159950029000 $60025 \mathrm{x}$

Weng JH, Liao TS, Sun KH, Chung JC, Lin CP, Chu $\mathrm{CH}$ (2005). Seasonal variations in photosynthesis of Picea morrisonicola growing in the subalpine region of subtropical Taiwan. Tree Physiology 25 (8): 973-979. - doi: 10.1093/treephys/ 25.8.973

$\mathrm{Xu} \mathrm{CY}$, Hosseini-Bai S, Hao Y, Rachaputi RCN, Wang H, Xu Z, Wallace H (2015). Effect of biochar amendment on yield and photosynthesis of peanut on two types of soils. Environmental Science and Pollution Research 22 (8): 6112-6125. - doi: 10.1007/s11356-014-3820-9

Yuanyuan M, Yali Z, Jiang L, Hongbo S (2010). Roles of plant soluble sugars and their responses to plant cold stress. African Journal of Biotechnology 8 (10): 2004-2010. [online] URL: http://www.ajol.info/index.php/ajb/article/view/ 60470
Zahedifar M, Najafian S (2017). Ocimum basilicum L. growth and nutrient status as influenced by biochar and potassium-nano chelate fertilizers. Archives of Agronomy and Soil Science 63 (5): 638-650. - doi: 10.1080/03650340.2016.1233323 Zemanova V, Brendova K, Pavlikova D, Kubatova $P$, Tlustos $P$ (2017). Effect of biochar application on the content of nutrients ( $\mathrm{Ca}, \mathrm{Fe}, \mathrm{K}, \mathrm{Mg}, \mathrm{Na}$, $P)$ and amino acids in subsequently growing spinach and mustard. Plant, Soil and Environment 63 (7): 322-327. - doi: 10.17221/318/2017-PSE

\section{Supplementary Material}

Appendix 1 - Equations used for calculation of leaf biochemical traits and photosynthetic pigments.

Appendix 2 - Light-response curves of photosynthesis fitting.

Tab. S1 - Physiochemical properties of soil and hardwood biochar.
Fig. S1 - Seasonal comparison in conductance to $\mathrm{H}_{2} \mathrm{O}$ of seedling at different photosynthetic photon flux density levels (PPFD) under different hardwood biochar (BH) levels.

Fig. S2 - Seasonal comparison in intercellular $\mathrm{CO}_{2}$ concentration of seedling at different photosynthetic photon flux density levels (PPFD) under different hardwood biochar $(\mathrm{BH})$ levels.

Fig. S3 - Seasonal comparison in transpiration rate of seedling at different photosynthetic photon flux density levels (PPFD) treated with different hardwood biochar (BH) levels.

Fig. S4 - Metrological information of study area, during the entire experiment period

Link:Tarin_3416@supploo1.pdf 